\title{
GMR
}

\section{Simulating the selfing and migration of Luehea divaricata populations in the Pampa biome to investigate the conservation potential of their genetic resources}

\author{
C.M.L. Serrote ${ }^{1}$, L.R.S. Reiniger ${ }^{2}$, V.M. Stefenon ${ }^{3}$, A.R. Curti ${ }^{4}$, \\ L.S. Costa ${ }^{2}$ and A.F. Paim ${ }^{2}$ \\ ${ }^{1}$ Departamento de Silvicultura e Manejo Florestal, \\ Faculdade de Ciências Agrárias, Universidade Lúrio, Campus Universitário, \\ Unango, Mozambique \\ ${ }^{2}$ Núcleo de Biotecnologia e Melhoramento, Universidade Federal de Santa Maria, \\ Campus Sede, Santa Maria, RS, Brasil \\ ${ }^{3}$ Núcleo de Genômica e Ecologia Molecular, Universidade Federal do Pampa, \\ Campus São Gabriel, São Gabriel, RS, Brasil \\ ${ }^{4}$ Departamento de Fitotecnia, Faculdade de Agronomia Eliseu Maciel, \\ Universidade Federal de Pelotas, Campus Universitário, Capão do Leão, RS, \\ Brasil
}

Corresponding author: L.R.S. Reiniger

E-mail: liarsr@ufsm.br

Genet. Mol. Res. 15 (3): gmr.15038410

Received January 8, 2016

Accepted June 13, 2016

Published August 29, 2016

DOI http://dx.doi.org/10.4238/gmr.15038410

Copyright $(2016$ The Authors. This is an open-access article distributed under the terms of the Creative Commons Attribution ShareAlike (CC BY-SA) 4.0 License.

ABSTRACT. Computer simulations are an important tool for developing conservation strategies for forest species. This study used simulations to investigate the genetic, ecological, and reproductive patterns that contribute to the genetic structure of the tree Luehea 
divaricata Mart. \& Zucc. in five forest fragments in the Brazilian Pampa biome. Using the EASYPOP model, we determined the selfing and migration rates that would match the corresponding genetic structure of microsatellite marker data (based on observed and expected heterozygosity parameters). The simulated reproductive mode was mixed, with a high rate of outcrossing (rate $=0.7$ ). This was consistent with a selfing-incompatible system in this species, which reduced, but did not prevent, selfing. The simulated migration rate was 0.02 , which implied that the forest fragments were isolated by distance, and that the inbreeding coefficients were high. Based on Nei's gene diversity analysis, $94 \%$ of the genetic variability was distributed within the forest fragments, and only $6 \%$ of the genetic diversity was caused by differences between them. Furthermore, the minimum viable population and minimum viable area genetic conservation parameters (which determine conservation potential in the short and long term) suggested that only the Inhatinhum forest fragment had the short-term potential to maintain its genetic diversity. However, in the long term, none of the forest fragments proved to be sustainable, indicating that the populations will require intervention to prevent a decline in genetic variability. The creation of ecological corridors could be a useful solution to connect forest fragments and enhance gene flow between them.

Key words: EASYPOP simulations; Gene flow; Tropical grasslands; Forestry species fragmentation; Nei's gene diversity analysis; Inbreeding coefficients

\section{INTRODUCTION}

The fragmentation of various ecosystems through anthropogenic actions represents a threat to the maintenance and viability of natural populations. Owing to their demographic and reproductive characteristics, tropical species are particularly vulnerable to the effects of habitat fragmentation. Such characteristics include low population densities, complex and self-incompatible breeding systems, high rates of outcrossing (Cascante et al., 2002), and specialized interactions with pollinators and seed dispersers (Didham et al., 1996). Furthermore, when pollinators have a limited range, because they cannot make long-distance flights, and when there is a low density of local floral resources, the geographic isolation of species can result in reproductive isolation. In addition, seed dispersers may not move between fragmented habitats because of predation pressure, which restricts the majority of outcrossing to the interior of these fragments. This results in an increased genetic drift that can fix certain alleles at the expense of others, thereby reducing genetic variability (Lowe et al., 2005; Quesada et al., 2013).

In the short term, populations with reduced genetic variability exhibit increased susceptibility to diseases, pests, and abiotic agents such as frost. Furthermore, forced inbreeding by an increase in the rate of biparental crossings and selfing increases the susceptibility to an inbreeding depression. An inbreeding depression occurs when there is an increase in the expression of deleterious alleles that were previously masked by dominant

Genetics and Molecular Research 15 (3): gmr.15038410 
genes in heterozygous individuals. In the long term, a reduction of genetic variability reduces a species' evolutionary flexibility (i.e., the ability of populations to respond to changes in selection pressures). Therefore, genetic variability is essential for the adaptation, evolution, and survival of a species. This is particularly important when species are under pressure from environmental changes, pests, or diseases. Overall, conserving genetic variability is extremely important (Lowe et al., 2005; Vinson et al., 2015).

Integrating information about historical population processes, including the distribution of alleles and genotypes, is important for selecting priority areas for conservation (Moritz and Faith, 1998). Gene flow is a critical factor for the distribution of genetic variation, because a high gene flow tends to homogenize genetic structures, whereas a low gene flow allows for the non-random distribution of alleles and genotypes. Therefore, understanding the connectivity of individuals within and among populations is a primary aspect of population ecology, evolution, and conservation (Nagel et al., 2015).

Given the importance of population size in the conservation of genetic variability, conservation efforts have resulted in the concept of a minimum viable population (MVP). The MVP is defined as the size of a population below which genetic effects are more severe, making the risk of extinction of a species extremely high. Because this parameter is dependent on reproductive, demographic, and genetic aspects, it is important to study it in targeted conservation populations (Peng et al., 2013).

With advances in information technology, new methods and simulation programs have been developed in evolutionary biology, which allow inferences about past events from current data. Such programs and simulations can provide new insights regarding the evolutionary relationships between simple molecular characteristics, genes, genomes, and species. In addition to the programs that perform backward-time simulations (coalescence), programs that perform forward-time simulations have also been developed. These allow for predictions of future outcomes under real genetic scenarios (Yuan et al., 2012). In our study, we conducted simulations using the EASYPOP program (Balloux, 2001), based on data from microsatellite markers obtained from the forest tree species Luehea divaricata Mart. \& Zucc. The trees originated from five different forest fragments in the Brazilian Pampa biome. Such a biome is characterized by the fragmented distribution of formations (Nagel et al., 2015), affecting the genetic, ecological, and reproductive patterns of its species with a risk of extinction. Our objective was to study the genetic, ecological, and reproductive patterns that best explain the genetic structure, to gain a better understanding of the evolutionary history and provide input for conservation planning. More specifically, we focused on the following research questions: 1) what selfing and migration rates correspond best to the information derived from microsatellite data for L. divaricata?; and 2) based on these results, which of the five forest fragments have viable $L$. divaricata populations in the short and long term?

\section{MATERIAL AND METHODS}

\section{Research area}

The five studied forest fragments are located in the State of Rio Grande do Sul, Brazil (Figure 1A and B). More specifically, they are: Camboazinho (100 estimated L. divaricata individuals in the fragment), Canas (100 individuals), Inhatinhum (300 individuals), Cacequi (100 individuals), and BR290 (50 individuals). The estimated number of L. divaricata

Genetics and Molecular Research 15 (3): gmr.15038410 
individuals per fragment was based on a phytosociological survey performed in 2013 (Stefenon VM, unpublished results). Furthermore, the data to verify the genetic simulations were obtained from Nagel et al. (2015). L. divaricata was used as a model for this simulation study, because of its ecological importance and the possibility of local threat by the expansion of agriculture, livestock, and urban growth in the Pampa biome. Microsatellite genetic markers were used to evaluate the genetic structure and gene flow of $L$. divaricata in the five forest fragments.
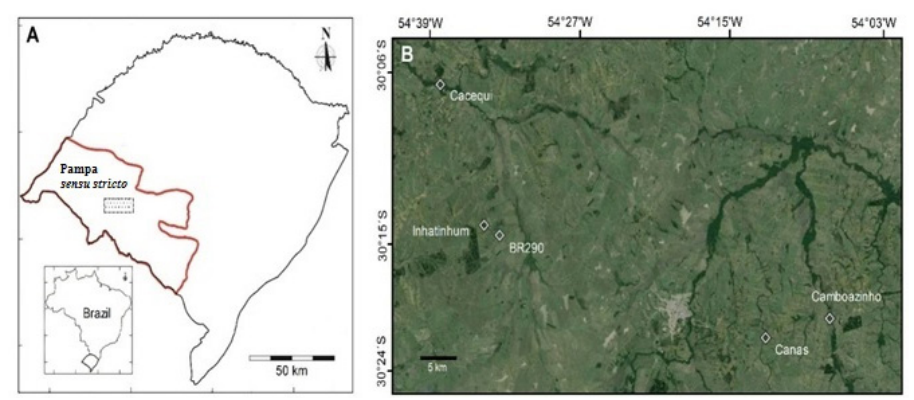

Figure 1. Boundaries of the Pampa biome sensu stricto in southern Brazil; sample area highlighted (A). Geographic location of five fragments of Luehea divaricata plotted on satellite images of the Pampa biome, used in the molecular characterization and simulations of this study (B). Source: Nagel et al. (2015).

\section{Model settings and simulations}

The computer program EASYPOP version 2.0.1 (Balloux, 2001) was used to determine the rates of selfing and migration that would result in parameters similar to those determined by Nagel et al. (2015). Generally, EASYPOP is used to simulate population genetic datasets, and it includes various mutation and migration models. In our simulations, we changed the selfing from 0.1 to 0.5 in steps of 0.1 . For migration, the simulations ranged between 0.1 and 0.9 , with steps of 0.1 .

The model was simulated for a diploid hermaphrodite species with non-random outcrossing and no clonal reproduction. A spatial migration model was based on the geographic location of the fragments, which were obtained from the real geographical coordinates (latitude and longitude) according to the map.

For the mutation settings, we simulated 5 and 10 loci that evolved according to the single-step mutation (SSM), with a proportion of $0.1 \mathrm{~K}$-allele model (KAM) events, under 45 possible allelic states, according to the data obtained by Ruas et al. (2009), Conson (2012), and Nagel et al. (2015). A mutation rate of 0.0004 mutations per locus per generation was assumed. The genetic variability of the initial population was considered the maximum, and we simulated 400 generations. For each combination of selfing and migration rates, 100 replicates were performed.

\section{FSTAT analyses}

We used the observed $\left(H_{\mathrm{O}}\right)$ and expected heterozygosities $\left(H_{\mathrm{E}}\right), 0.52$ and 0.64 , respectively, from Nagel et al. (2015) to select the model settings that presented values closest to the field observations (Tables 1 and 2). $H_{\mathrm{O}}$ and $H_{\mathrm{E}}$ values of the selected model (selfing 
and migration) were compared with others by two independent sample $t$-tests at a $5 \%$ level of probability of error.

The output files of the selected model were subsequently analyzed using the FSTAT program (Goudet, 1995). FSTAT is a computer package that estimates and tests gene diversities and differentiation statistics from codominant genetic markers. Using FSTAT, we obtained statistics to characterize the forest fragments, including allelic richness, genetic diversity, and indices of genetic differentiation among populations, following the approaches of Wright (1965), Cockerham (1969), and Nei (1977). Because this study used microsatellite loci that presumably evolved according to step-by-step mutations, a statistic indicating the genetic distances between populations was also included. Here, we used the $R_{\mathrm{ST}}$ statistic, which is the most indicative estimate for genetic differentiation between populations. Gene flow was estimated by the average number of migrants per generation, based on the proportion of the total genetic variance in a subpopulation $\left(F_{\mathrm{ST}}\right)$ and $R_{\mathrm{ST}}$.

Furthermore, the coefficient of inbreeding within the fragments $\left(F_{\text {IS }}\right)$ was used to estimate the rate of apparent outcrossing $\left(T_{\mathrm{a}}\right)$, given by the equation of Nei and Syakudo (1958):

$$
t_{a}=\frac{1-F_{\mathrm{IS}}}{1+F_{\mathrm{IS}}}
$$

The estimated gene flow was determined in terms of the average number of migrants per generation $\left(N_{\mathrm{m}}\right)$ from the value of $R_{\mathrm{ST}}$, and followed the equation of Nagel et al. (2015):

$$
N_{\mathrm{m}}=\frac{1}{4}\left(\frac{1}{R_{\mathrm{ST}}}-1\right)
$$

Values of $N_{\mathrm{m}}$ for each pair of fragments were also estimated, based on respective pairwise $F_{\text {ST }}$ values.

\section{Genetic parameters for conserving natural $L$. divaricata populations}

Based on the obtained statistics, the following conservation parameters were determined: the effective population size $\left(N_{\mathrm{E}}\right)$, the MVP, and the minimum viable area (MVA) per forest fragment. The $N_{\mathrm{E}}$ was determined by the level of inbreeding, and corresponded to the representative size of the fragment $(N)$, given the inbreeding coefficient $f$, using the equation of Pollak and Sabran (1992):

$$
N_{\mathrm{E}}=\frac{\mathrm{N}}{1+f}
$$

MVP was estimated for each fragment by dividing the reference effective size $\left(N_{\mathrm{E}}\right.$ (ref.)) by the ratio of $N_{\mathrm{E}}$ and $N$, according to Vieira and Carvalho (2008). The difference $(D)$ between the sample size and the MVP was calculated as follows (Vieira and Carvalho, 2008):

$$
D=d * A-\frac{N_{\mathrm{E}(r e f .)}}{N_{\mathrm{E} / \mathrm{N}}}
$$

Genetics and Molecular Research 15 (3): gmr.15038410 
where $d$ is the density of the species (we used the value of 26.32 individuals/ha estimated previously by Figueiredo (2014) for $L$. divaricata in the Pampa biome), $A$ is the fragment area (ha), $N$ is the sample size of each fragment, and $N_{\mathrm{E}}$ (ref.) is the effective reference size adopted for 100 or 1000 individuals for short- or long-term conservation, respectively (Nunney and Campbell, 1993). Fragments with positive $D$ values were considered viable for conservation, whereas those with negative values were classified as unviable. MVA was estimated using the equation given by Silva et al. (2014):

$$
M V A=\frac{N^{*} N_{\mathrm{E}(r e f .)}}{d^{*} N_{\mathrm{E}}}
$$

(Equation 5)

\section{RESULTS AND DISCUSSION}

\section{Selection of model parameters}

The EASYPOP simulations resulted in similar $H_{\mathrm{O}}$ and $H_{\mathrm{E}}$ values for all the used selfing and migration rates, based on two independent sample $t$-tests at a $5 \%$ level of probability (Tables 1 and 2). Depending on the results, additional migration rates were tested at a selfing rate of 0.3 . The model with a selfing rate of 0.3 and a migration rate of 0.02 was selected as the best fit for the data obtained by microsatellite markers. Within this rate of selfing, the values of both $H_{\mathrm{O}}$ and $H_{\mathrm{E}}$ at the rate of migration of 0.02 were significantly different from the other rates, based on two independent sample $t$-tests at a $5 \%$ level of probability of error.

Table 1. Estimates of observed $\left(H_{\mathrm{O}}\right)$ and expected $\left(H_{\mathrm{E}}\right)$ heterozygosities generated by simulations in the EASYPOP program, according to different rates of selfing, migration to 5 loci and 45 possible allelic states, from five fragments of Luehea divaricata.

\begin{tabular}{|c|c|c|c|c|c|c|c|c|c|c|}
\hline \multirow{3}{*}{ Migration rate } & \multicolumn{10}{|c|}{ Rate of selfing } \\
\hline & \multicolumn{2}{|c|}{0.1} & \multicolumn{2}{|c|}{0.2} & \multicolumn{2}{|c|}{0.3} & \multicolumn{2}{|c|}{0.4} & \multicolumn{2}{|c|}{0.5} \\
\hline & $H_{\mathrm{O}}$ & $H_{\mathrm{E}}$ & $H_{\mathrm{O}}$ & $H_{\mathrm{E}}$ & $H_{\mathrm{O}}$ & $H_{\mathrm{E}}$ & $H_{\mathrm{O}}$ & $H_{\mathrm{E}}$ & $H_{\mathrm{O}}$ & $H_{\mathrm{E}}$ \\
\hline 0.01 & & & & & 0.510 & 0.612 & & & & \\
\hline 0.02 & & & & & 0.524 & 0.630 & & & & \\
\hline 0.03 & & & & & 0.533 & 0.646 & & & & \\
\hline 0.05 & & & & & 0.536 & 0.650 & & & & \\
\hline 0.1 & 0.660 & 0.695 & 0.601 & 0.675 & 0.548 & 0.667 & 0.487 & 0.646 & 0.417 & 0.624 \\
\hline 0.2 & 0.666 & 0.702 & 0.611 & 0.685 & 0.556 & 0.672 & 0.502 & 0.665 & 0.434 & 0.649 \\
\hline 0.3 & 0.668 & 0.705 & 0.619 & 0.696 & 0.566 & 0.686 & 0.505 & 0.673 & 0.434 & 0.652 \\
\hline 0.4 & 0.677 & 0.713 & 0.626 & 0.704 & 0.573 & 0.692 & 0.510 & 0.680 & 0.448 & 0.671 \\
\hline 0.5 & 0.688 & 0.726 & 0.642 & 0.720 & 0.579 & 0.702 & 0.517 & 0.688 & 0.456 & 0.680 \\
\hline 0.6 & 0.697 & 0.734 & 0.641 & 0.721 & 0.583 & 0.705 & 0.515 & 0.690 & 0.460 & 0.687 \\
\hline 0.7 & 0.790 & 0.740 & 0.655 & 0.735 & 0.594 & 0.721 & 0.527 & 0.700 & 0.459 & 0.689 \\
\hline 0.8 & 0.695 & 0.733 & 0.654 & 0.734 & 0.595 & 0.722 & 0.526 & 0.701 & 0.460 & 0.690 \\
\hline 0.9 & 0.704 & 0.742 & 0.646 & 0.726 & 0.594 & 0.721 & 0.525 & 0.702 & 0.455 & 0.682 \\
\hline
\end{tabular}

\section{Characterization of forest fragments}

For genetic characterization of the forest fragments and subsequent analysis, the model with 10 loci and 45 possible allelic states was selected, because its values were similar to those of the model with 5 loci and 45 possible allelic states. Overall, the mode of reproduction of the population could be characterized as mixed, with a predominance of outcrossing, according to the classification of Destro and Montalván (1999). The outcrossing rate was 0.7, suggesting the

Genetics and Molecular Research 15 (3): gmr.15038410 
presence of a system of self-incompatibility in this species that reduced, but did not completely prevent selfing. According to Bawa (1974), self-incompatibility is frequently used by angiosperms to prevent the adverse effects of inbreeding and the subsequent loss of genetic variability.

Table 2. Estimates of observed $\left(H_{\mathrm{O}}\right)$ and expected $\left(H_{\mathrm{E}}\right)$ heterozygosities generated by simulations in the EASYPOP program, according to different rates of selfing, migration to 10 loci and 45 possible allelic states, from five fragments of Luehea divaricata.

\begin{tabular}{|c|c|c|c|c|c|c|c|c|c|c|}
\hline \multirow{3}{*}{ Migration rate } & \multicolumn{10}{|c|}{ Rate of selfing } \\
\hline & \multicolumn{2}{|c|}{0.1} & \multicolumn{2}{|c|}{0.2} & \multicolumn{2}{|c|}{0.3} & \multicolumn{2}{|c|}{0.4} & \multicolumn{2}{|c|}{0.5} \\
\hline & $H_{\mathrm{O}}$ & $H_{\mathrm{E}}$ & $H_{\mathrm{O}}$ & $H_{\mathrm{E}}$ & $H_{\mathrm{O}}$ & $H_{\mathrm{E}}$ & $H_{\mathrm{O}}$ & $H_{\mathrm{E}}$ & $H_{\mathrm{O}}$ & $H_{\mathrm{E}}$ \\
\hline 0.01 & & & & & 0.510 & 0.615 & & & & \\
\hline 0.02 & & & & & 0.525 & 0.636 & & & & \\
\hline 0.03 & & & & & 0.535 & 0.647 & & & & \\
\hline 0.05 & & & & & 0.542 & 0.658 & & & & \\
\hline 0.1 & 0.655 & 0.690 & 0.601 & 0.675 & 0.543 & 0.659 & 0.487 & 0.646 & 0.417 & 0.625 \\
\hline 0.2 & 0.671 & 0.707 & 0.611 & 0.685 & 0.556 & 0.672 & 0.502 & 0.665 & 0.434 & 0.643 \\
\hline 0.3 & 0.668 & 0.706 & 0.619 & 0.696 & 0.568 & 0.689 & 0.505 & 0.673 & 0.437 & 0.653 \\
\hline 0.4 & 0.679 & 0.715 & 0.626 & 0.704 & 0.567 & 0.688 & 0.510 & 0.680 & 0.443 & 0.663 \\
\hline 0.5 & 0.692 & 0.730 & 0.642 & 0.720 & 0.576 & 0.698 & 0.517 & 0.688 & 0.452 & 0.678 \\
\hline 0.6 & 0.697 & 0.736 & 0.641 & 0.721 & 0.585 & 0.709 & 0.515 & 0.690 & 0.452 & 0.678 \\
\hline 0.7 & 0.699 & 0.736 & 0.655 & 0.735 & 0.589 & 0.714 & 0.527 & 0.700 & 0.462 & 0.692 \\
\hline 0.8 & 0.696 & 0.735 & 0.654 & 0.734 & 0.587 & 0.713 & 0.526 & 0.701 & 0.458 & 0.686 \\
\hline 0.9 & 0.701 & 0.739 & 0.646 & 0.726 & 0.587 & 0.713 & 0.525 & 0.702 & 0.457 & 0.687 \\
\hline
\end{tabular}

Rates of selfing and outcrossing in species with mixed systems of reproduction depend on ecological factors, such as population density, as well as the abundance and effectiveness of pollinators (Lobo et al., 2013). In fragmented or disturbed environments, species respond to a scarcity of pollinators with increased selfing rates to guarantee reproduction. Therefore, fragmentation and the consequent reproductive isolation of fragments (with gene flow restricted to proximate fragments) resulted in outcrossing rates below 0.88 , which is the average recorded for natural populations of arboreal hardwood species (Sobierajski et al., 2006). This suggests that self-incompatibility alleles were lost through genetic drift, which allowed individuals to self-fertilize successfully at higher rates. Lobo et al. (2013) studied the reproductive system in a disturbed population of Ceiba pentandra (Malvaceae) in different years, which yielded outcrossing rates of 0.759 (2007) and 0.624 (2009). These values are similar to those obtained in our study, and are probably the result of a reduction in gene flow caused by fragmentation.

However, the presence of self-incompatibility systems in hermaphrodite and homogametic species is important for avoiding an inbreeding depression, and to maintain the potential to respond to evolutionary pressures. Quesada et al. (2013) observed the outcrossing rates of Ceiba aesculifolia (Malvaceae) for 4 years. The observed rates were close to 1.0 in disturbed and undisturbed environments, because this species has a rigorous self-incompatibility mechanism. Moraes and Monteiro (2002) estimated the apparent outcrossing rates in Cryptocarya moschata, and observed a differential advantage of individuals from outcrossed seeds compared with those from self-fertilized seeds. Overall, these results, together with our findings, suggest selection against individuals from inbred seeds caused by an inbreeding depression.

The derived migration rate of 0.02 underestimated the actual movement of pollen and seeds, because it only considers successful migration. If this were the real rate of migration, all the pollen that moved from one fragment to another would be viable and would be deposited on the stigma of a receptive flower, would overcome all barriers of incompatibility, form the 
pollen tube, and produce a viable seed. Under favorable environmental conditions, that seed would subsequently germinate, emerge, grow, and develop. Furthermore, the derived migration rate assumes that at maturity, the tree would contribute its genes to future generations. In relation to the flow via seeds, their viability would be dependent upon soils with adequate conditions for germination, growth, development, maturation, and reproduction. Overall, the derived migration rate should be considered as the effective rate of migration, rather than the total movement of pollen or seeds.

Isolation by distance restricts most outcrossing to the interior of the forest fragments. This increases the rate of biparental outcrossing and selfing by limiting the movement of pollinators and seed dispersers. Consequently, this leads to an increase of the inbreeding coefficient. The molecular characterization and simulations of the areas shown in Figure 1, as well as the distances between the forest fragments, were estimated by Nagel et al. (2015). The latter suggested that gene exchange occurs between Canas and Camboazinho (8513 m apart), and between Inhatinhum, Cacequi, and BR290 (Inhatinhum and BR290 are $2200 \mathrm{~m}$ apart; Inhatinhum and Cacequi are 16,084 m apart; and Cacequi and BR290 are 18,063 m apart). Furthermore, Canas and BR290 are 36,224 m apart, and Camboazinho and Cacequi are 56,167 $\mathrm{m}$ apart. The dendrogram obtained using estimates of genetic distance from microsatellite data supports this finding. This finding is in agreement with the dendrogram obtained by Nagel et al. (2015) using estimates of genetic distance obtained from microsatellite data.

Because we used microsatellite data, the SSM model (loss or gain of a single repetition at a time) limited to 45 allelic states was appropriate, with the occurrence of KAM events at a ratio of 0.1 . The stepwise mutation model (SMM) is the basic model in which microsatellite loci evolve, and consists of a gain or loss of a unity of repetition (Valdes et al., 1993). In other words, $90 \%$ of the mutations result in an allelic state, for which the size depends on the previous one, and in $10 \%$ of the cases, they result in an allele with any possible allelic state at an equal probability. The initial maximum variability model explains the reduction of genetic variability along the 400 generations according to inbreeding and genetic drift caused by fragmentation. Although mutations increase genetic variability, their low rate could counter neither the effects of isolation, nor the consequent low gene flow between fragments.

\section{Genetic structure of forest fragments}

The parameters for genetic structure demonstrate that allelic richness and genetic variability increase according to the size of the forest fragment (Table 3). However, the differences among the forest fragments were not large. This is supported by the respective values of allelic richness. Stefenon and Costa (2012) performed simulations to determine the effect of fragmentation on allelic richness and the inbreeding coefficient over 1000 generations. These simulations revealed that, compared with the larger population, over generations, the smaller populations experienced larger reductions in allelic richness and increases in their inbreeding coefficients. This observation underlines the importance of population size in the preservation of genetic variability and in minimizing the risk of extinction.

Figure 2 illustrates changes in the number of alleles over the course of 400 generations. There was a marked rate of allele loss in the early generations, with relative stability achieved at generation 100. After generation 100, half of the initial number of alleles had already been lost through inbreeding and genetic drift. After 400 generations, the number of alleles per locus was reduced from 45 to 5 .

Genetics and Molecular Research 15 (3): gmr.15038410 
Table 3. Number of individuals in the fragment $(\mathrm{N})$, number of alleles $\left(N_{\mathrm{A}}\right)$, allelic richness $\left(A_{\mathrm{r}}\right)$, expected heterozygosity $\left(H_{\mathrm{E}}\right)$, inbreeding coefficient within the fragment $\left(F_{\mathrm{IS}}\right)$, and apparent outcrossing rate $\left(\mathrm{t}_{a}\right)$ per fragment of Luehea divaricata, obtained from microsatellite data and analyzed using the FSTAT program.

\begin{tabular}{l|c|c|c|c|c|c}
\hline & Camboazinho & Canas & Inhatinhum & Cacequi & BR290 & Total \\
\hline $\mathrm{N}$ & 100 & 100 & 300 & 100 & 50 & 650 \\
\hline$N_{\mathrm{A}}$ & 5 & 5 & 6 & 5 & 5 & 5 \\
\hline$A_{\mathrm{r}}$ & 5.27 & 5.31 & 5.52 & 5.24 & 5.18 & 6.24 \\
\hline$H_{\mathrm{E}}$ & 0.637 & 0.635 & 0.641 & 0.637 & 0.631 & 0.636 \\
\hline$F_{\mathrm{IS}}$ & 0.183 & 0.168 & 0.180 & 0.175 & 0.173 & 0.176 \\
\hline$\widehat{\mathrm{t}}_{a}$ & 0.691 & 0.712 & 0.694 & 0.702 & 0.705 & 0.701 \\
\hline
\end{tabular}

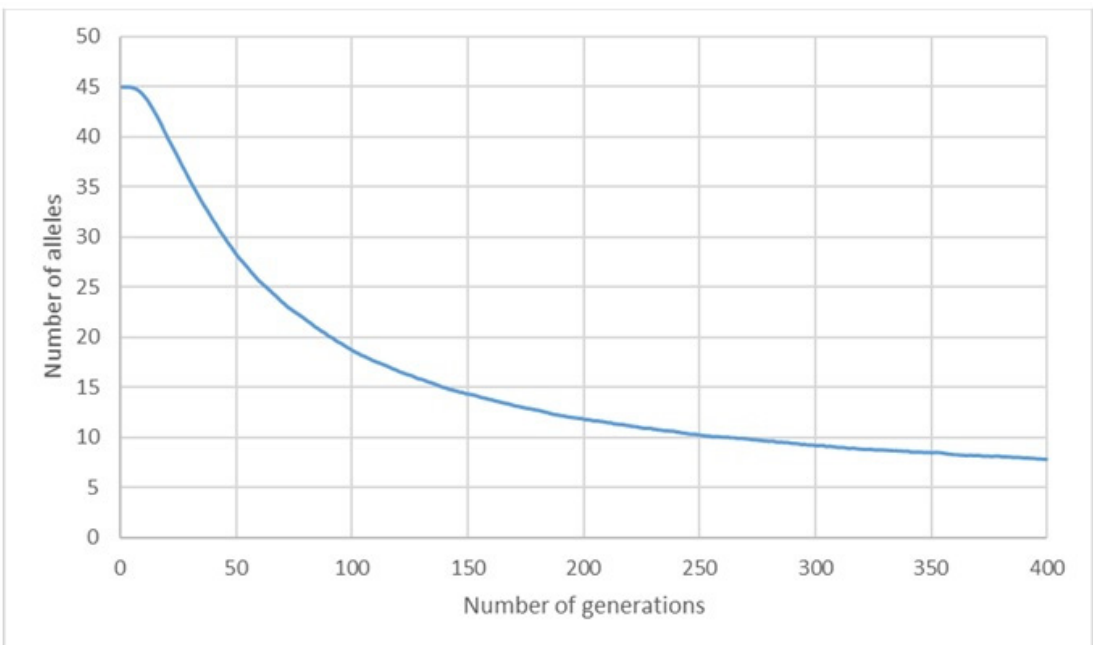

Figure 2. Evolution of the number of alleles with the passing of 400 generations in five fragments of Luehea divaricata.

The Inhatinhum forest fragment had the highest allelic richness (5.52; Table 3). The reduced genetic differentiation among the forest fragments, as evaluated by the indices of genetic differentiation $\left(G_{\mathrm{ST}}, F_{\mathrm{ST}}\right.$, and $\theta$; Table 4), indicated a similarity in allelic frequencies. This suggests that, despite the reproductive isolation, the forest fragments had similar evolutionary models, including their genetic drift intensity and direction, natural selection, and mutation rates and models.

Based on Nei's measure of genetic diversity (Table 5), 94\% of the genetic variability was distributed within the forest fragments, and only $6 \%$ was distributed among them. The large variability observed within the fragments resulted from the high rate of outcrosses, which confirms previous results in relation to the mixed reproduction mode with a predominance of outcrosses. Similar results were obtained by Conson (2012), who analyzed microsatellite loci from nine populations of the same species in the Atlantic Forest. Conson reported that $93.16 \%$ of the variation was distributed within the populations, and only $6.84 \%$ between them.

Genetics and Molecular Research 15 (3): gmr.15038410 
Table 4. Statistics for genetic structure under various approaches, generated by the FSTAT program, for five fragments of Luehea divaricata.

\begin{tabular}{l|c|c}
\hline \multirow{2}{*}{ Nei's statistics } & $H_{\mathrm{O}}$ & 0.524 \\
\cline { 2 - 3 } & $H_{\mathrm{E}}$ & 0.636 \\
\cline { 2 - 3 } & $H_{\mathrm{T}}$ & 0.678 \\
\cline { 2 - 3 } & $D_{\mathrm{ST}}$ & 0.042 \\
\cline { 2 - 3 } & $G_{\mathrm{ST}}$ & 0.061 \\
\cline { 2 - 3 } & $G_{\mathrm{IS}}$ & 0.238 \\
\cline { 2 - 3 } & $\mathrm{F}$ & 0.075 \\
\cline { 2 - 3 } & 0 & 0.176 \\
\cline { 2 - 3 } & $F_{\mathrm{IT}}$ & 0.226 \\
\cline { 2 - 3 } & $F_{\mathrm{ST}}$ & 0.061 \\
\cline { 2 - 3 } & $F_{\mathrm{IS}}$ & 0.176 \\
\hline Wright's F-statistics & $R_{\mathrm{ST}}$ & 0.076 \\
\hline Statistics of genetic differentiation adapted for microsatellites & $N_{\mathrm{m}}$ & 3.8 \\
\hline Gene flow & $\mathrm{f}$ & \\
\hline
\end{tabular}

$H_{\mathrm{O}}$ : observed heterozygosity within fragments; $H_{\mathrm{E}}$ : expected heterozygosity within fragments; $H_{\mathrm{T}}$ : total heterozygosity; $D_{\mathrm{ST}}$ : genetic diversity among fragments; $G_{\mathrm{ST}}$ : coefficient of genetic divergence among fragments (relative diversity); $G_{\mathrm{IS}}$ : diversity within fragments; F: total coancestry coefficient; $\theta$ : coefficient of correlation of gametes among fragments; f: coancestry coefficient within the fragments; $F_{\mathrm{IT}}$ : total inbreeding coefficient; $F_{\mathrm{ST}}$ : coefficient of inbreeding among fragments; $F_{\mathrm{IS}}$ : coefficient of inbreeding within the fragments.

Table 5. Nei's indices of genetic diversity among and within five fragments of Luehea divaricata.

\begin{tabular}{l|c|c}
\hline Source of variation & Absolute diversity & Relative diversity \\
\hline Between populations $\left(D_{\mathrm{ST}}\right)$ & 0.042 & 0.06 \\
\hline Within populations $\left(H_{\mathrm{E}}\right)$ & 0.636 & 0.94 \\
\hline Total $\left(H_{\mathrm{T}}\right)$ & 0.678 & \\
\hline
\end{tabular}

The differentiation statistics were similar within $\left(G_{\mathrm{IS}}, f\right.$, and $\left.F_{\mathrm{IS}}\right)$ and between the forest fragments $\left(G_{\mathrm{ST}}, \theta, F_{\mathrm{ST}}\right.$, and $\left.R_{\mathrm{ST}}\right)$, even when using different statistical approaches (Table 4). Because the values of $F_{\mathrm{ST}}$ and $\mathrm{R}_{\mathrm{ST}}$ were similar, the forest fragments were probably evolving in the same direction. According to do Valle et al. (2011), the difference between these statistics is caused by the evolutionary process of the forest fragments (i.e., their differentiated in time according to their evolutionary models). The estimate of $R_{\mathrm{ST}}$ was similar to $\theta$, as expected (Slatkin, 1995), because both were based on components of interpopulational variance; their values ( 0.076 and 0.075 , respectively) revealed a moderate differentiation among fragments, according to the scale provided by Hartl and Clark (2010).

The Camboazinho forest fragment exhibited the highest inbreeding coefficient, caused by the lowest rate of outcrossing (0.691). Likewise, the Canas forest fragment, which had the lowest inbreeding coefficient, had the highest rate of outcrossing (0.712). Alves et al. (2013) investigated Theobroma grandiflorum at different Embrapa research centers in Brazil, such as CPAFRO (municipality of Porto Velho, RO), CPAA (Manaus, AM), and CPATU (Belém, PA). They did not observe inbreeding in the population $(f=0.003)$, the mean coancestry value was low $(\theta=0.0199)$, and the number of alleles observed was 45 , in the genetic characterization of 24 accessions of $T$. grandiflorum, using microsatellite markers. Similar results $(f=0.002$ and $F$ $=0.07$ ) were obtained by Moura et al. (2012) when studying the genetic structure in fragmented populations of Solanum lycocarpum A. St.-Hil. in the Cerrado region of Brazil. According to Slatkin (1995), the values of $F_{\text {IS }}$ may be overestimated, owing to the high mutation rates of microsatellite loci. Consequently, there is a greater likelihood that the alleles are identical 
by state (mutations that result in a size equal to a repeating unit), rather than by descent. In addition, sample size plays an important role in the accuracy of the inbreeding estimate. Larger sample sizes result in fewer sampling errors, whereas small samples are less likely to capture all possible genotypes of each locus, resulting in overestimation of inbreeding.

Gene flow, expressed as the average number of migrants per generation, was 3.8 (Table 4). This is a high value according to the scale set by Govindaraju (1989). This scale distinguishes between three levels of gene flow: high $\left(N_{\mathrm{m}}>1\right)$, intermediate $\left(0.25<N_{\mathrm{m}}<\right.$ $0.99)$, and low $\left(N_{\mathrm{m}}<0.25\right)$. At 3.8, the gene flow among our forest fragments would be high enough to counter the effects of evolutionary forces (inbreeding and genetic drift), and result in less differentiation among the fragments. However, it is an overrated value because the expression used to estimate the number of migrants per generation was developed for Wright's Island Model. This model differs from the isolation by distance model of this case study, which restricts the flow to more proximate fragments.

Pairwise differentiation indicated a greater differentiation between the Cacequi and BR290 forest fragments because of the lower gene flow between them (Table 6). In contrast, the Canas and Inhatinhum forest fragments exhibited the lowest genetic differentiation. These data are in contrast with the first law of geography (Tobler, 1970). According to this law, less differentiation is expected between the pairs that are geographically closest together, such as the Canas and Camboazinho, and Inhatinhum and BR290 forest fragments. Likewise, a greater differentiation would be expected between forest fragments that are geographically further apart, such as Cacequi and Camboazinho, and Cacequi and Canas. However, phenomena such as self-incompatibility, a restriction of gene flow, or the reproductive failure of migrants can help explain why this first law of geography does not apply to our data. Similarly, no significant correlation was found between the pairwise $F_{\mathrm{ST}}$ and geographical distances in the study of Conson (2012). Apparently, geographical proximity between fragments does not necessarily mean genetic proximity. Furthermore, Medri et al. (2011) found significant correlation between genetic differentiation and geographic distance among nine subpopulations of the tropical tree species Aegiphila sellowiana (Lauraceae), in Brazil.

Table 6. Pairwise estimates of $F_{\mathrm{ST}}$ (upper diagonal) and gene flow (lower diagonal) of five fragments of Luehea divaricata.

\begin{tabular}{l|c|c|c|c|c}
\hline & Camboazinho & Canas & Inhatinhum & Cacequi & BR290 \\
\hline Camboazinho & - & 0.078 & 0.065 & 0.077 & 0.081 \\
\hline Canas & 2.974 & - & 0.061 & 0.076 & 0.078 \\
\hline Inhatinhum & 3.610 & 3.853 & - & 0.064 & 0.058 \\
\hline Cacequi & 2.976 & 3.041 & 3.666 & - & 0.082 \\
\hline BR290 & 2.826 & 2.950 & 4.055 & 2.793 & - \\
\hline
\end{tabular}

The number of migrants per generation between forest fragment pairs was overestimated, because some pairs do not exchange genes, owing to the distance between them. Furthermore, $F_{\mathrm{ST}}$ is not suitable for genetic analysis of microsatellite loci, because loci evolve according to the step-by-step mutation model, which makes the $R_{\mathrm{ST}}$ statistic more appropriate. However, the indirect estimation of gene flow based on genetic differentiation statistics $\left(F_{\mathrm{ST}}\right.$ or $R_{\mathrm{ST}}$ ) assumes a genetic structure according to the Wright model (which assumes uniformity and constancy in time and space for the population size and migration rate). This assumption is not appropriate for the model of migration observed in this study, because some of our forest fragments were isolated by distance. Although the island model is more conventional (Sork et

Genetics and Molecular Research 15 (3): gmr.15038410 
al., 1999), it does not reflect the contemporary movement of genes or changes in the process of dispersal between populations, and therefore, the gene flow is called historical or apparent. Nevertheless, the island model provides valuable information about cumulative effects of gene flow in the genetic structure of populations.

The decline in allele numbers and the heterozygosity over 400 generations are illustrated in Figures 2 and 3, respectively. Initially, there was a high rate of allele loss and the number of alleles was reduced to approximately 18 after 100 generations. Thereafter, the number of alleles stabilized, ending with approximately 7 alleles after 400 generations. The loss of alleles over time was accompanied by a reduction in observed and expected heterozygosities, for which the initial values were 0.83 and 0.97 , respectively, but those values reached 0.52 and 0.64 after 400 generations. The reduction in heterozygosity occurred more slowly than the loss of alleles in the first 100 generations, demonstrating the importance of outcrossing for the recombination of remaining alleles to generate variability.

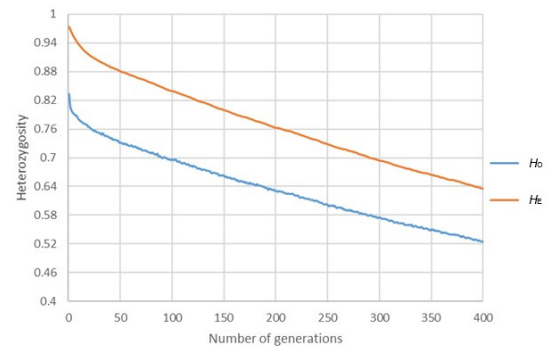

Figure 3. Behavior of observed $\left(H_{\mathrm{O}}\right)$ and expected $\left(H_{\mathrm{E}}\right)$ heterozygosities across 400 generations in five fragments of Luehea divaricata.

The heterozygosity values were plotted as a function of the number of generations for the lower (0.01, Figure 4A) and higher ( 0.9 , Figure 4B) rates of migration, to illustrate the effect of the rate of migration on the loss of genetic variability. Figure 4A demonstrates that having a gene flow rate of 0.01 would result in the values of current heterozygosity $(0.52$ and 0.64$)$ after 360 generations. Conversely, under an increased gene flow, this heterozygosity would have been reached after 400 generations, and genetic variability would be even higher (Figure 4B). Once again, these data corroborate the important role of gene flow in the prevention of genetic variability loss in populations.

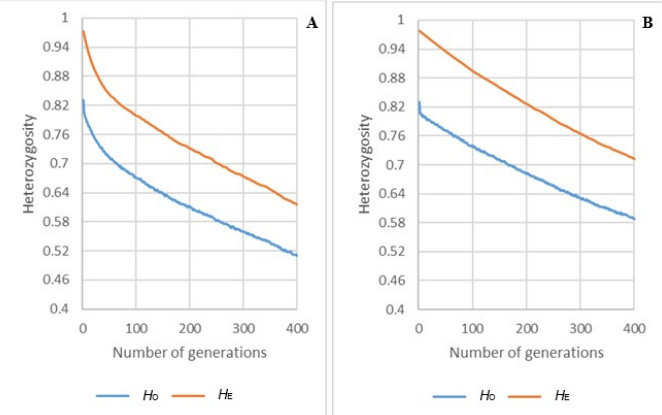

Figure 4. Observed $\left(H_{\mathrm{O}}\right)$ and expected $\left(H_{\mathrm{E}}\right)$ heterozygosities considering a migration rate of $1 \%$ in five fragments of Luehea divaricata (A). Observed and expected heterozygosities considering a migration rate of $90 \%$ (B). 
The area between the curves of expected and observed heterozygosities tends to decrease over generations (Figure 4B). These differences between the parameters $\left(H_{\mathrm{E}}-H_{\mathrm{O}}\right)$, together with the inbreeding coefficients for the 0.02 and 0.9 migration ratios, illustrate the impact of gene flow on inbreeding in the five forest fragments (Figure 5). The decline in the $H_{\mathrm{E}}-H_{\mathrm{O}}$ plot for the 0.02 migration rate was sharper than for the 0.9 migration rate. Furthermore, there was a stabilization of the inbreeding coefficient for both rates of migration, despite a slight upward trend with the migration rate of 0.02 that was primarily observed during the early generations. However, throughout the generations, $H_{\mathrm{O}}$ tended to be close to $H_{\mathrm{E}}$. The population with a migration rate of $0.02 \mathrm{had}$ a tendency to reach the Hardy-Weinberg equilibrium earlier than the population with a migration rate of 0.9 , given the same initial values of heterozygosity. This is because, at a 0.02 migration rate, the loss of heterozygosity is faster and the expected heterozygosity declines at a higher rate than that observed. Therefore, it reaches equilibrium earlier, despite the low gene flow.

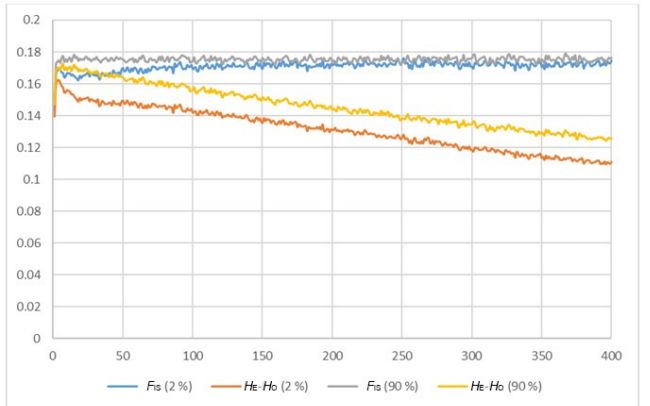

Figure 5. Differences between the heterozygosities $\left(H_{\mathrm{E}}-H_{\mathrm{O}}\right)$ and the fixation index as a function of the number of generations in five fragments of Luehea divaricata.

A plot of the $F$-statistics shows how the effects of isolated forest fragments and the reproductive system contributed to the total inbreeding, or the deviation of panmixia, of the total population $\left(F_{\mathrm{IT}}\right)$ (Figure 6A and B). Because of the lack of differentiation among the fragments, the $F_{\text {IS }}$ and $F_{\text {IT }}$ plots overlap at a migration rate of 0.9 . This indicates that the inbreeding caused by the subdivision of forests was insignificant, and the inbreeding observed was virtually caused by the reproductive system of the populations. Nevertheless, the migration rate of 0.02 provides a margin for inbreeding to occur owing to isolation, apart from the effect of the reproductive system.

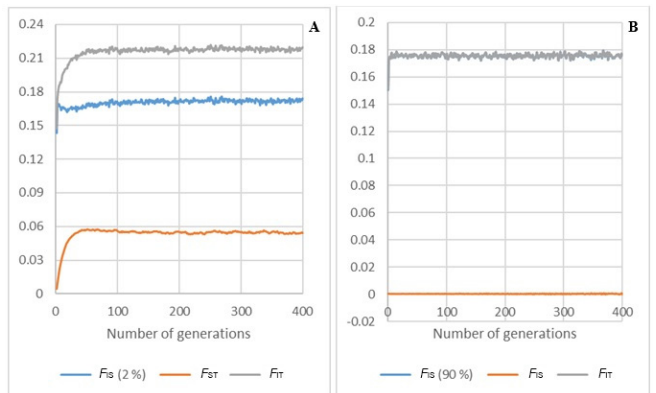

Figure 6. Plot of the Wright $F$-statistics for a migration rate of 0.02 in five fragments of Luehea divaricata (A). Plot of the Wright $F$-statistics for a migration rate of $0.9(\mathbf{B})$.

Genetics and Molecular Research 15 (3): gmr.15038410 


\section{Parameters for genetic conservation}

The MVP and MVA values (Table 7) are of great importance in the conservation of genetic resources. They minimize the effects of the factors that lead to the extinction of alleles and, consequently, the extinction of species.

Table 7. Parameters for genetic conservation of the population in five fragments of Luehea divaricata.

\begin{tabular}{|c|c|c|c|c|c|}
\hline & Camboazinho & Arroio Canas & Fazenda Inhatinhum & Rio Cacequi & BR290 \\
\hline $\mathrm{N}$ & 100 & 100 & 300 & 100 & 50 \\
\hline$F_{\text {IS }}$ & 0.183 & 0.168 & 0.18 & 0.175 & 0.173 \\
\hline$N_{\mathrm{E}}$ & 84.53 & 85.62 & 254.24 & 85.11 & 42.63 \\
\hline$N_{\mathrm{E}} / \mathrm{N}$ & 0.85 & 0.86 & 0.85 & 0.85 & 0.85 \\
\hline $\mathrm{D}$ & 26.32 & 26.32 & 26.32 & 26.32 & 26.32 \\
\hline A & 3.8 & 3.8 & 11.4 & 3.8 & 1.9 \\
\hline $\operatorname{MVP}_{(100)}$ & 118 & 117 & 118 & 117 & 117 \\
\hline $\mathrm{D}_{(100)}$ & -18 & -17 & 182 & -17 & -67 \\
\hline $\operatorname{MVP}_{(1000)}$ & 1183 & 1168 & 1180 & 1175 & 1173 \\
\hline $\mathrm{D}_{(1000)}$ & -1083 & -1068 & -880 & -1075 & -1123 \\
\hline $\operatorname{MVA}_{(100)}$ & 4.5 & 4.4 & 4.5 & 4.5 & 4.5 \\
\hline $\operatorname{MVA}_{(1000)}$ & 45 & 44.4 & 44.8 & 44.6 & 44.6 \\
\hline
\end{tabular}

$\mathrm{N}$ : size of the fragment; $N_{\mathrm{E}}$ : effective population size; $F_{\mathrm{IS}}$ : coefficient of inbreeding within the fragments; D: population density (individuals/ha); A: fragment area (ha); $\mathrm{MVP}_{(100)}$ and $\mathrm{MVP}_{(1000)}$ : minimum viable population for conservation in the short and long term, respectively; $\mathrm{MVA}_{(100)}$ and $\mathrm{MVA}_{(1000)}$ : minimum viable area for short- and long-term conservation, respectively; $\mathrm{D}_{(100)}$ and $\mathrm{D}_{(1000)}$ : difference between the size and the MVP of the fragment in the short and long term, respectively.

The effective population size $\left(N_{\mathrm{E}}\right)$ for all populations was smaller than the number of individuals sampled, which can be explained by the occurrence of inbreeding $\left(F_{\text {IS }}>0\right)$. The Inhatinhum forest fragment, which was larger and revealed a lower inbreeding estimation, had the highest $N_{\mathrm{E}}$. The values in Table 7 suggest that a sample of 85 individuals selected at random would represent the genetic variability in the existing population in Camboazinho with 100 individuals. The Canas population, in turn, with the same number of individuals, but with a slightly lower fixation index, is represented genetically by 86 individuals. This difference is caused by the fact that inbreeding reduces the genetic variability of the population, and is concentrated in a subpopulation that is smaller than the total population size. At one extreme, if the fixation index or inbreeding coefficient is equal to zero, the total genetic variability will be distributed in all the individuals of the population. After sampling 20 individuals from two populations of the forest tree Calophyllum brasiliense, Botrel et al. (2006) obtained effective population sizes of inbreeding of 18.24 and 19.59 for conservation purposes, using the same algorithm used in the present study.

The $N_{\mathrm{E}} / N$ ratio is an important parameter in the preservation of germplasm, seed collections, and in situ gene conservation (Vieira and Carvalho, 2008). Because the fixation index was similar in the five fragments, the $N_{\mathrm{E}} / N$ ratio also had similar values. Therefore, no specific subpopulation was a priority for conservation over the others, because in general, populations with lower $N_{\mathrm{E}} / N$ ratios have a higher priority for conservation than others. In addition, no different strategies for seed collection were needed because more sampling is generally necessary in ecosystems with lower $N_{\mathrm{E}} / N$ ratios to ensure the maintenance of genetic variability and a minimum of inbreeding in seeds (Vieira and Carvalho, 2008). Nevertheless, because the high inbreeding coefficients resulted in a low $N_{\mathrm{E}} / N$ ratio, conservation and seed

Genetics and Molecular Research 15 (3): gmr.15038410 
collection strategies are necessary, and must be carried out randomly across parent trees.

The MVP, determined to help prevent a short-term inbreeding depression, and to maintain the long-term evolutionary potential of a population, was calculated for $N_{\mathrm{E}}$ sizes of 100 and 1000, as recommended by Nunney and Campbell (1993). According to Lynch and Lande (1998), the mean genetic variance becomes independent of population size when $N_{\mathrm{E}}$ exceeds 1000 individuals, and therefore, this scenario is the appropriate limit for long-term conservation. In our study, the same density $(D)$ was assumed in all subpopulations, based on the value obtained in the survey conducted by Figueiredo (2014) in the municipality of São Martinho da Serra, Rio Grande do Sul, Brazil. Only the Inhatinhum forest fragment presented possibilities for maintaining the genetic diversity in a short-term genetic equilibrium. This was because it achieved a positive $D$ value, which represents the difference between the size of the estimated population and the MVP. However, none of the forest fragments was able to preserve its evolutionary potential in the long term (i.e., all $D$ values were negative), which increased the likelihood of random-genetic fluctuations that might have led to its decline. Likewise, Vieira and Carvalho (2008) obtained negative values of $D$, both for short-term and long-term conservation. Therefore, urgent strategies to reduce inbreeding and allele loss through genetic drift are necessary. One solution for our fragments would be to create and protect ecological corridors to maintain gene flow between them.

The conversion of the MVP into terms of area (MVA) suggests that each forest fragment requires at least 4.5 ha for short-term conservation goals, and 45 ha for long-term conservation. In keeping with other findings, only the Inhatinhum forest fragment has an area (11 ha) capable of preventing a short-term inbreeding depression. If the forest fragment remains this size and does not include any gene flow, the genetic variability will decline. Connecting the Canas and Camboazinho fragments, which together cover 7.6 ha, would create an area that would be sufficient for their short-term viability. For the remaining three subpopulations, given their geographic location, all would need to be connected and behave as a single panmictic population to allow significant gene flow. However, connecting the three subpopulations (total area of $24.7 \mathrm{ha}$ ) would not create an area large enough for the long-term MVA (45 ha), or for maintaining the population's evolutionary potential (long term). Nevertheless, because inbreeding was the decisive effect in the reduction of the effective population size, with the consequent increase of the MVP, connecting the five forest fragments through an increased gene flow could reduce the loss of alleles caused by genetic drift, and reduce inbreeding. This would result in an even lower MVP (and MVA), making the population close to or lower than the current area of 24.7 ha. For example, if the inbreeding coefficient in the first fragment (Camboazinho) was zero, its effective size would be equal to the population size, and the MVA would be 3.8 and 38 ha for short- and long-term conservation, respectively.

Under the conditions of this simulation, in which high levels of inbreeding because of reproductive isolation were observed, the forest fragment size alone is not enough to preserve its long-term evolution potential, unless the forest fragments are connected through some kind of gene flow. In the short term, only the Inhatinhum forest fragment is large enough to overcome the effects of inbreeding depression. Therefore, we propose the construction of ecological corridors connecting the Canas and BR290 forest fragments, and the Inhatinhum and Cacequi fragments. In this way, gene flow would be facilitated by the so-called 'stepping stone model', through which each fragment exchanges genes with adjacent fragments. This would allow gene flow between fragments and consequently minimize the effects of genetic drift and inbreeding. In addition, gene flow would facilitate allele distribution, including those alleles

Genetics and Molecular Research 15 (3): gmr.15038410 
generated by mutations. Furthermore, the ecological corridors would allow the recombination of genes with the features present in distant fragments, which would increase the genetic diversity and adaptive capacity of the entire population as a function of environmental change.

\section{Conflicts of interest}

The authors declare no conflict of interest.

\section{ACKNOWLEDGMENTS}

Research supported by Conselho Nacional de Desenvolvimento Científico e Tecnológico $(\mathrm{CNPq})$. We would like to thank Editage (www.editage.com.br) for English language editing.

\section{REFERENCES}

Alves RM, Silva CRS, Silva MSC, Silva DCS, et al. (2013). Diversidade genética em coleções amazônicas de germoplasma de cupuaçuzeiro. Rev. Bras. Frutic. 35: 818-828. http://dx.doi.org/10.1590/S0100-29452013000300019

Balloux F (2001). EASYPOP (version 1.7): a computer program for population genetics simulations. J. Hered. 92: 301302. http://dx.doi.org/10.1093/jhered/92.3.301

Bawa KS (1974). Breeding systems of tree species of a lowland tropical community. Evolution 28: 85-92.

Botrel MCG, Souza AM, Carvalho D, Pinto SIC, et al. (2006). Caracterização genética de Calophyllum brasiliense Camb. em duas populações de mata ciliar. Rev. Arvore 30: 821-827. http://dx.doi.org/10.1590/S0100-67622006000500016

Cascante A, Quesada M, Lobo JJ and Fuchs EA (2002). Effects of dry tropical forest fragmentation on the reproductive success and genetic structure of the tree Samanea saman. Conserv. Biol. 16: 137-147. http://dx.doi.org/10.1046/ j.1523-1739.2002.00317.x

Cockerham CC (1969). Variance of gene frequency. Evolution 23: 72-84.

Conson ARO (2012). Estrutura Genética em Populações de Luehea divaricata Mart. (Malvaceae). 58f. Master's thesis, Genetics and Molecular Biology, UEL, Londrina. http://www.uel.br/portal/frmOpcao.php?opcao=http://www. bibliotecadigital.uel.br/teses_dissertacoes.php. Accessed June 11, 2016.

Destro D and Montalván R (1999). Melhoramento Genético de Plantas. 1st edn. UEL Press, Londrina.

Didham RK, Ghazoul J, Stork NE and Davis AJ (1996). Insects in fragmented forests: a functional approach. Trends Ecol. Evol. 11: 255-260.http://dx.doi.org/10.1016/0169-5347(96)20047-3

do Valle GE, Zucchi MI, Stabellini NS, Lourenção AL, et al. (2011). Estrutura genética populacional de Bemisia tabaci (Gennadius) (Hemiptera: Aleyrodidae) utilizando marcadores microssatélites. Neotrop. Entomol. 40: 204-211.http:// dx.doi.org/10.1590/S1519-566X2011000200008

Figueiredo MCS (2014). Florística de mata ciliar em São Martinho da Serra, RS, Brasil. 65f. Dissertação, Master's thesis, UFSM, Santa Maria. http://w3.ufsm.br/ppgagrobio/MariaCarolina.pdf. Accessed June 8, 2016.

Goudet J (1995). FSTAT (Version 1.2): a computer program to calculate F-statistics. J. Hered. 86: 485-486.

Govindaraju DR (1989). Variation in gene flow levels among predominantly self-pollinated plants. J. Evol. Biol. 2: 173181. http://dx.doi.org/10.1046/j.1420-9101.1989.2030173.x

Hartl DL and Clark AC (2010). Princípios de genética de populações, 4th edn. Artmed Press, Porto Alegre.

Lobo J, Solis S, Fuchs EJ and Quesada M (2013). Individual and temporal variation in outcrossing rates and pollen flow patterns in Ceiba pentandra (Malvaceae: Bombacoidea). Biotropica 45: 185-194. http://dx.doi.org/10.1111/ btp. 12001

Lowe AJ, Boshier D, Ward M, Bacles CF, et al. (2005). Genetic resource impacts of habitat loss and degradation; reconciling empirical evidence and predicted theory for Neotropical trees. Heredit 95: 255-273. http://dx.doi. org/10.1038/sj.hdy. 6800725

Lynch M and Lande R (1998). The critical effective size for a genetically secure population. Anim. Conserv. 1: 70-72. http://dx.doi.org/10.1111/j.1469-1795.1998.tb00229.x

Medri C, Ruas EA, Ruas CF, Medri PS, et al. (2011). Population genetic structure of the tropical tree species Aegiphila sellowiana (Lamiaceae). Genet. Mol. Res. 10: 3186-3198.http://dx.doi.org/10.4238/2011.December.20.3

Genetics and Molecular Research 15 (3): gmr.15038410 
Moraes PLR and Monteiro R (2002). Taxas de cruzamento em uma população natural de Cryptocarya moschata Nees (Lauraceae). Biota Neotrop. 2: 1-10.

Moritz C and Faith DP (1998). Comparative phylogeography and the identification of genetically divergent areas for conservation. Mol. Ecol. 7: 419-429. http://dx.doi.org/10.1046/j.1365-294x.1998.00317.x

Moura TM, Martins K, Sujii PS, Sebbenn AM, et al. (2012). Genetic structure in fragmented populations of Solanum lycocarpum A. St.-Hil. with distinct anthropogenic histories in a Cerrado region of Brazil. Genet. Mol. Res. 11: 26742682. http://dx.doi.org/10.4238/2012.July.10.16

Nagel JC, Ceconi DE, Poletto I and Stefenon VM (2015). Historical gene flow within and among populations of Luehea divaricata in the Brazilian Pampa. Genetica 143: 317-329.http://dx.doi.org/10.1007/s10709-015-9830-9

Nei M (1977). F-statistics and analysis of gene diversity in subdivided populations. Ann. Hum. Genet. 41: 225-233. http:// dx.doi.org/10.1111/j.1469-1809.1977.tb01918.x

Nei M and Syakudo K (1958). The estimation of outcrossing in natural populations. Jpn. J. Genet. 33: 46-51. Available at [https://www.jstage.jst.go.jp/article/ggs1921/33/2/33_2_46/_pdf]. Accessed June 11, 2016. http://dx.doi. org/10.1266/jig. 33.46

Nunney L and Campbell KA (1993). Assessing minimum viable population size: Demography meets population genetics. Trends Ecol. Evol. 8: 234-239.http://dx.doi.org/10.1016/0169-5347(93)90197-W

Peng B, Chen HS, Mechanic LE, Racine B, et al. (2013). Genetic Simulation Resources: a website for the registration and discovery of genetic data simulators. Bioinformatics 29: 1101-1102. http://dx.doi.org/10.1093/bioinformatics/btt094

Pollak E and Sabran M (1992). On the theory of partially inbreeding finite populations. III. Fixation probabilities under partial selfing when heterozygotes are intermediate in viability. Genetics 131: 979-985.

Quesada M, Herrerías-Diego Y, Lobo JA, Sánchez-Montoya G, et al. (2013). Long-term effects of habitat fragmentation on mating patterns and gene flow of a tropical dry forest tree, Ceiba aesculifolia (Malvaceae: Bombacoideae). Am. J. Bot. 100: 1095-1101. http://dx.doi.org/10.3732/ajb.1200542

Ruas EA, Conson ARO, Costa BF, Damasceno JO, et al. (2009). Isolation and characterization of ten microsatellite loci for the tree species Luehea divaricata Mart. (Malvaceae) and intergeneric transferability. Conserv. Genet. Resour. 1: 245-248. http://dx.doi.org/10.1007/s12686-009-9060-5

Silva SMM, Martins K, Mesquita AGG and Wadt LHO (2014). Parâmetros genéticos para a conservação de Hymenaea courbaril L. na Amazônia Sul-Ocidental. Cienc. Florest. 24: 87-95. http://dx.doi.org/10.5902/1980509813326

Slatkin M (1995). A measure of population subdivision based on microsatellite allele frequencies. Genetics 139: 457-462. Available at [http://www.genetics.org/content/genetics/139/1/457.full.pdf].

Sobierajski GR, Kageyama PY and Sebbenn AM (2006). Sistema de reprodução em nove populações de Mimosa scabrella Bentham (Leguminosaceae). Sci. Forestalis 71: 37-49.

Sork VL, Nason J, Campbell DR and Fernandez JF (1999). Landscape approaches to historical and contemporary gene flow in plants. Trends Ecol. Evol. 14: 219-224.http://dx.doi.org/10.1016/S0169-5347(98)01585-7

Stefenon VM and Costa LS (2012). A simulation study on the behavior of allelic richness and inbreeding coefficient over generations in fragmented populations of tree species. Ann. For. Res. 55: 3-10.

Tobler WR (1970). A computer movie simulating urban growth in the Detroit region. Econ. Geogr. 46: 234-240. http:// dx.doi.org/10.2307/143141

Valdes AM, Slatkin M and Freimer NB (1993). Allele frequencies at microsatellite loci: the stepwise mutation model revisited. Genetics 133: 737-749.

Vieira FA and Carvalho D (2008). Genetic structure of an insect-pollinated and bird-dispersed tropical tree in vegetation fragments and corridors: implications for conservation. Biodivers. Conserv. 17: 2305-2321. http://dx.doi.org/10.1007/ s10531-008-9367-7

Vinson CC, Kanashiro M, Harris SA and Boshier DH (2015). Impacts of selective logging on inbreeding and gene flow in two Amazonian timber species with contrasting ecological and reproductive characteristics. Mol. Ecol. 24: 38-53. http://dx.doi.org/10.1111/mec. 13002

Wright S (1965). The interpretation of population structure by F-statistics with special regard to systems of mating. Evolution 19: 395-420.

Yuan X, Miller DJ, Zhang J, Herrington D, et al. (2012). An overview of population genetic data simulation. J. Comput. Biol. 19: 42-54. http://dx.doi.org/10.1089/cmb.2010.0188

Genetics and Molecular Research 15 (3): gmr.15038410 